\title{
Transforming the Entrepreneurial Landscape: Emergent Innovative Behaviors in Internet Firms
}

\author{
Jill Kickul \\ Lisa K. Gundry
}

The electronic marketplace presents an extraordinarily challenging environment for product and service development, and will necessitate the development of alternative entrepreneurship models. Internet entrepreneurial teams can be characterized by their orientation toward values of rapid change and innovation. This article reports on a study of innovative behaviors in which 131 internet entrepreneurs were engaged, and six distinct innovation activities emerged. Implications for opportunity identification, alliance formation, and strategic orientation of Internet entrepreneurs are presented as preliminary steps toward a new "netpreneurship" model of business formation.

$\mathbf{E}$ ntrepreneurship has always been a vibrant force in the economy, and at the forefront of adaptation and growth of new markets. As the 20th century drew to its closure, it had been described as the "century of the entrepreneur" (Bangs and Pinson, 1999). The entrepreneurial landscape continues to transform, and as the 21 st century unfolds, a new form of entrepreneurship is taking shape. With the rapid acceleration and availability of technology, electronic commerce is changing the nature of business. New forms of distribution, marketing, selling, and arranging work are observable. Attributes of this new economy, referred to as "netpreneurship," include:

- collapsing boundaries between firms, suppliers, customers, and competitors;

- new, expanding markets with increasing competition, choice, and lower prices;

- the presence of "infomediaries" who provide production information and locate the best selection or price;

- and shifting consumer expectations as buyers' tolerance for poor service and quality decreases (Morino, 1999).

This phenomenon will play an increasingly important role in business. However, because it is so recent, there is very little information known about the attributes or innovative activities of Internet entrepreneurs. Research is needed to identify success factors, including opportunities and barriers confronting this emerging group of enterprises. This article examines the innovative orientations that Internet entrepreneurs have incorporated into their firms. It reports on a study which represents one of the first empirical investigations of Internet entrepreneurial behavior, contributing to the development of a research agenda in this area.

\section{Netpreneurs: A New Breed of Business Ownership}

Electronic commerce experienced dynamic and rapid growth in the late 1990s. By the end of 1998, it was estimated that there were 97 million web users worldwide (International Data Corporation, 1999). By the year 2002, this number is expected to jump to 320 million users (International Data Corporation, 1999). In the United States alone, 9 million households shopped on-line in 1998, yielding $\$ 7.8$ billion in revenues for on-line businesses (Forrester Research, 1999). By 2003, 40 million U.S. households are expected to shop on the web, and revenues from this will approach $\$ 108$ billion (Forrester Research, 1999). These statistics reflect the increasing numbers of ventures that will be launched on the Internet.

Prospective entrepreneurs who want to capitalize on this trend will need to identify the factors necessary to successfully found and sustain this type of business. Effective "e-businesses" will seek out and act on the demands of the market, differentiating themselves through customer management, relationship marketing, and community building (Shannon, 1999). Netpreneurs will need to build organizations that have several dimensions paramount to effective performance (Morino, 1999). According to Morino, these are:

- Speed-Advances in computing and globalization have changed stakeholders' expectations about the pace of change.

- Adaptability-The business must be much more flexible and able to identify and respond to changes in technology, competition, and buyer patterns.

- Multidisciplinary and collaborative-These areas involve integrating such diverse disciplines as technology, services, and graphics.

The boundary where the enterprise starts and ends will become blurred, as extranets connect vendors and information networks of capabilities (Cohen and Jordan, 1999). 


\section{New Core Values of Netpreneurship: Innovation, Experimentation, and Change}

The rise of the WorldWideWeb and electronic commerce has created one of the most challenging environments for product and service development in recent history, where market needs and the technology required to meet these needs can change even while the product or service is still under development (lansiti and MacCormak, 1997). This framework demands that netpreneurs strive for "relentless innovation," leading their firms through the continual infusion of new ideas (Cohen and Jordan, 1999). A new set of core business values appears to distinguish Internet entrepreneurial teams from others. These values are constant innovation, experimentation, and rapid change. Such an orientation is similar to what Miller and Blais (1992) characterize as "maverick" behaviors in which firms adopt innovative modes based on their competencies, rompetitive situations, or managerial preferences. The environment of e-commerce enables firms to rapidly try new approaches, quickly share successes and failures, and monitor what is new and useful (Oliva, 1998). Drucker (1998) describes four areas of innovative opportunities that exist within a company or industry, including unexpected occurrences, incongruities, process needs, and industry and market changes. While these innovative opportunities may be present to Internet entrepreneurial teams, there may be additional areas for potential innovative actions.

This emphasis on innovation and change will be oriented not only to the outcomes of these organizations (e.g., products, services, new markets, etc.) but also to the structure and work arrangements of the ventures themselves. Oliva (1998) has noted that a successful Internet study needs to be designed to assess:

- To what extent have these entrepreneurs been engaged in innovations?

- What is the direction (type) of these business innovations?

This research is a preliminary exploration of the innovative orientation of "netpreneurs." It is designed to contribute to theory building in this area that is just newly emerging. While previous researchers have begun to examine the value orientation of entrepreneurial teams and found distinctive characteristics (Kecharananta and Baker, 1999), the present study is one of the first in the entrepreneurship field to examine this orientation among a group of Internet new ventures. Of primary interest is the investigation of the type and direction of innovations these entrepreneurs have introduced into their firms. Based on the emergent behaviors found in this study, the researchers propose a model for further development in this area that considers the relationship between innovative actions and the overall strategic orientation of these enterprises.

\section{Methods}

This section describes the methods used in conducting the investigation.

\section{Sample}

The study involved 131 entrepreneurs who conducted their business on the Internet. The sample was obtained through web-based associations and organizations whose main purpose is to disseminate information and ideas among Internet-based entrepreneurs. Information about this research investigation was posted on several Internet discussion/message lists: LinkExchange (www.linkexchange.com), Netpreneur.org (www.netpreneur.org), Arizona Internet Professionals Association (www.azipa. org), and Inc. Online: Doing Business Online (www. inc.com). The majority of the respondents were male $(81 \%)$, with over 15 years of business experience. Over half of the netpreneurs $(52 \%)$ had previously owned a business before launching their venture and 47 percent held a college degree. Approximately 35 percent were between the ages of 37 and 45 , with the next largest groups being between the ages of 25 and $36(29 \%)$ and the ages of 46 and $57(25 \%)$. These netpreneurs have involved three other individuals (mean $=3.47$ ) besides themselves on the management team for their current internet business. The average age of the Internet businesses surveyed was 6.19 years. These businesses had average revenues of $\$ 522,000$ (projected revenues for the following year was approximately $\$ 1.3$ million), and had an average of 18 fulltime employees.

\section{Overview and Procedure}

All information was gathered from the entrepreneurs over a two-month period, utilizing a new methodology for data collection: on-line survey completion. Participants were told that the study was being conducted to better understand how Internet-based entrepreneurs manage and operate their businesses. Entrepreneurs were informed that their candid opinions would help clarify the different approaches entrepreneurs, such as themselves, take in finding and implementing new ideas and opportunities within their respective markets. In addition to answering a series of questions on personal characteristics, the entrepreneurs were asked to provide information regarding the types of innovations implemented in their Internet business.

\section{Measures}

A 20-item innovation scale was developed to investigate the different types of innovative behaviors in which Internet entrepreneurs were engaged. This measure was based on the recent work of Pistrui (1999) who termed a series of entrepreneurial behaviors reflecting strategic characteris- 
tics-"implementable attributes of planned growth" (IAPG). The IAPG serves to operationalize Schumpeterian characteristics by identifying the specific types of new combinations entrepreneurs tend to pursue. These measures have been used in studies of entrepreneurial behaviors in North America and in Eastern Europe (Pistrui, Liao, and Welsch, 1998) and in research examining high-growth and lowgrowth orientations of entrepreneurs (Gundry and Welsch, 2000).

The innovative behaviors measure included:

- introducing new or improved services or products;

- implementing new technologies and technical processes;

- developing new marketing, promoting, advertising, or distribution methods;

- putting new employee training and incentive programs into practice; and

- adapting new business processes such as locationless or time-less functions. Participants were asked to indicate to what extent they had incorporated these innovations into their organization $(1=$ Not at all; $5=$ To a great extent).

\section{Results}

The results of the investigation are identified below.

\section{Entrepreneurs' Innovative Behaviors}

The 20-item innovation scale was submitted to a factor analysis using principal axis extraction and varimax rotation. A six-factor solution resulted as indicated through the interpretation of the scree plot (see Exhibit 1) and the eigenvalues greater than 1.0 . The first factor accounted for 26.9 percent of the variance while the remaining five factors combined accounted for an additional 45.6 percent.

As shown in Exhibit 2, factor 1 (4 items) was labeled incorporating additional marketing strategies. It measures those innovations related to having new customer promotions, new methods of advertising, improving the marketing of the product's/service's value, and new channels of distribution. Factor 2 ( 3 items), improving business process$e s$, assesses changes within the organization that allows for effective and efficient functioning. Factor 3 ( 3 items), managing human resources, measures whether new recruiting, training, and employee incentive programs have been adopted by the organization. Factor 4 ( 4 items) was labeled continuous product/service improvements. It assesses innovations associated with new improvements in new or existing products and services as well as the integration of new information technology to aid in understanding customers' demands and needs. Factor 5 (2 items), new technology resources, measures whether new computer technology or equipment is currently being used in the business. Finally, factor 6 (4 items), alternative mar- kets and opportunities, assesses those innovations related to venturing into new markets and customer segments. Cronbach's alpha of these six factors were: $.80, .87, .83$, $.75,90$, and .70 , respectively. Separate composite scores for each of these six scales were then calculated.

\section{Descriptive Statistics}

The means, standard deviations, and internal consistency reliabilities for the measures are reported in Exhibit 3. The reliabilities of the measures used were all at or over the .70 minimum established by Nunnally (1978). Of the innovative behaviors reported by Internet entrepreneurs, many of the highest rated factors included cóntinuous product/service improvements, alternative markets and opportunities, incorporating additional marketing strategies, and new technology resources. The lowest rated innovation factor, however, was managing human resources for these Internet firms.

As shown in Exhibit 3, there were discernable differences between continuous product/service improvements and the following factors: new technology resources, improving business processes, and managing human resources. Moreover, alternative markets and opportunities, incorporating additional marketing strategies, and new technology resources were all significantly different than improving business processes and managing human resources. Finally, there were significant differences between improving business processes and managing human resources.

\section{Discussion}

The primary objective of this study was to examine the type and direction of innovative actions incorporated by Internet entrepreneurs in their businesses. Through the analyses, the researchers uncovered six distinct innovative behaviors displayed by netpreneurs, ranging from continuous product/service improvements to managing human resources. These innovations varied to the extent that they were considered and implemented into the operations and business of the Internet firm. Improving products/services, seeking alternative markets and opportunities, and incorporating additional marketing strategies were the critical factors associated with initiating innovation and change. According to Koshiur (1997), netpreneurs must be continually prepared to make innovations and changes within the infrastructure of their business to meet and prepare for future opportunities and market/industry advancements.

Moreover, creative behavior and flexibility further allows the business to be a successful player in the virtual value chain -"converting the raw information into new services and products in the information world" (Koshiur, 1997: 103). The current electronic marketplace will necessitate new innovative models that deal with firm organization, pro- 


\section{Exhibit 1}

Internet Innovations: Scree Plot

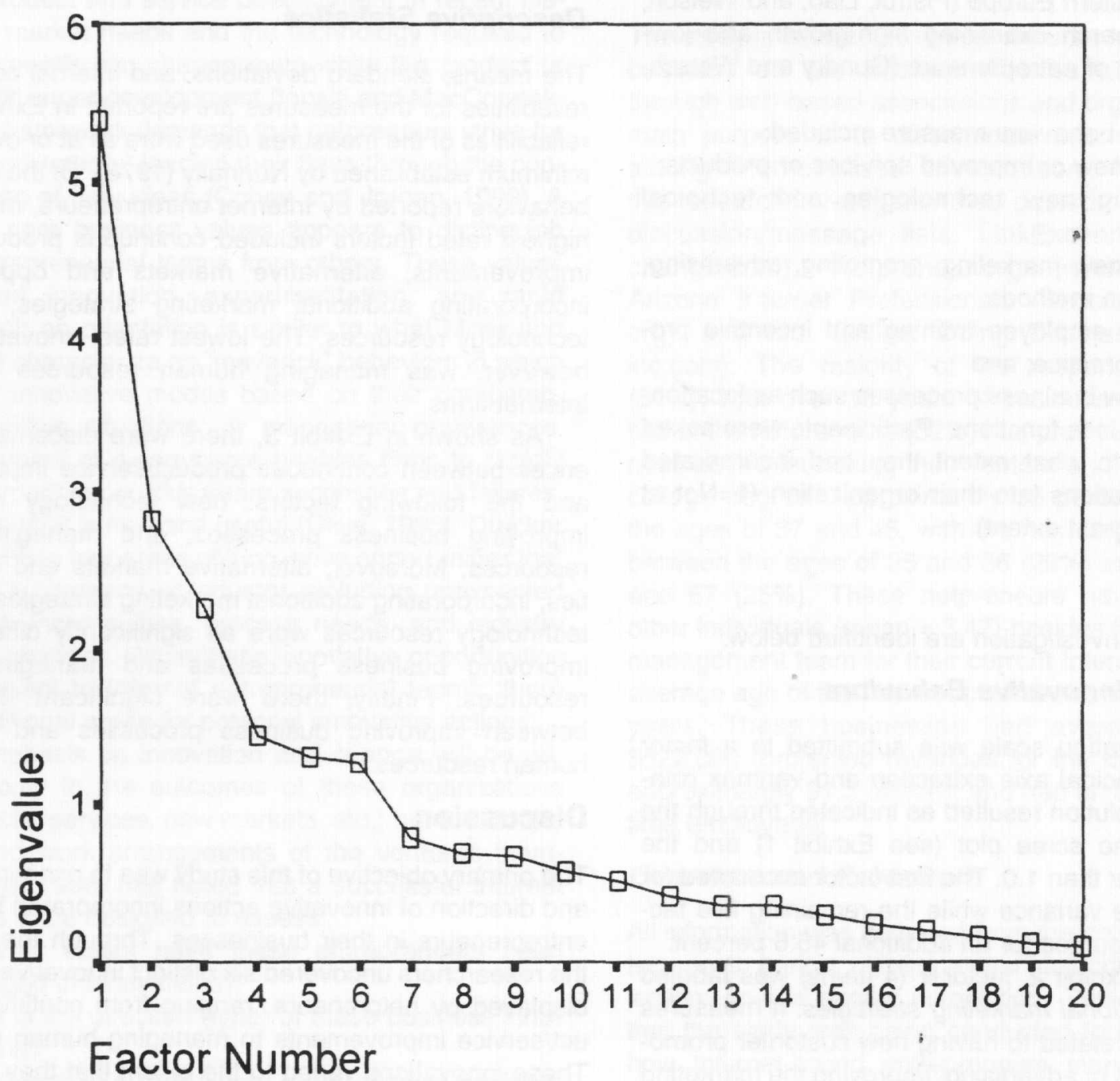

duction, and overall market institutions (Choi, Stahl, and Whinston, 1997; Lange, 1999). Indeed, as others have suggested (Cohen and Jordan, 1999; Oliva, 1998), Internet firms that emphasize innovation and rapid response to change are best positioned for success in this new form of entrepreneurship.

\section{Directions for Future Research: Towards a Model of Successful Internet Entrepreneurship}

While this study examined the various types of innovations engaged in by Internet entrepreneurs, future research should investigate how these innovations are related to the firm's strategic focus and orientation. More work should test the strategic requirements for successful Internet enterprise developments that have been proposed in the literature, including: How do the strategic orientations of first-to-market, first-follower, competitive aggressiveness, and rapid response to change predict innovative behavior? Does the enactment of innovative marketing behaviors, for example, give competitive advantage to these firms? What types (direction) of innovative actions seem to matter most to the firm's ability to respond rapidly to change?

Given the rapid pace of technology and business, Davis and Meyer (1998) have asserted that there is a greater need to be connected with suppliers, customers, and business partners. This need for connectivity forces Internet- 


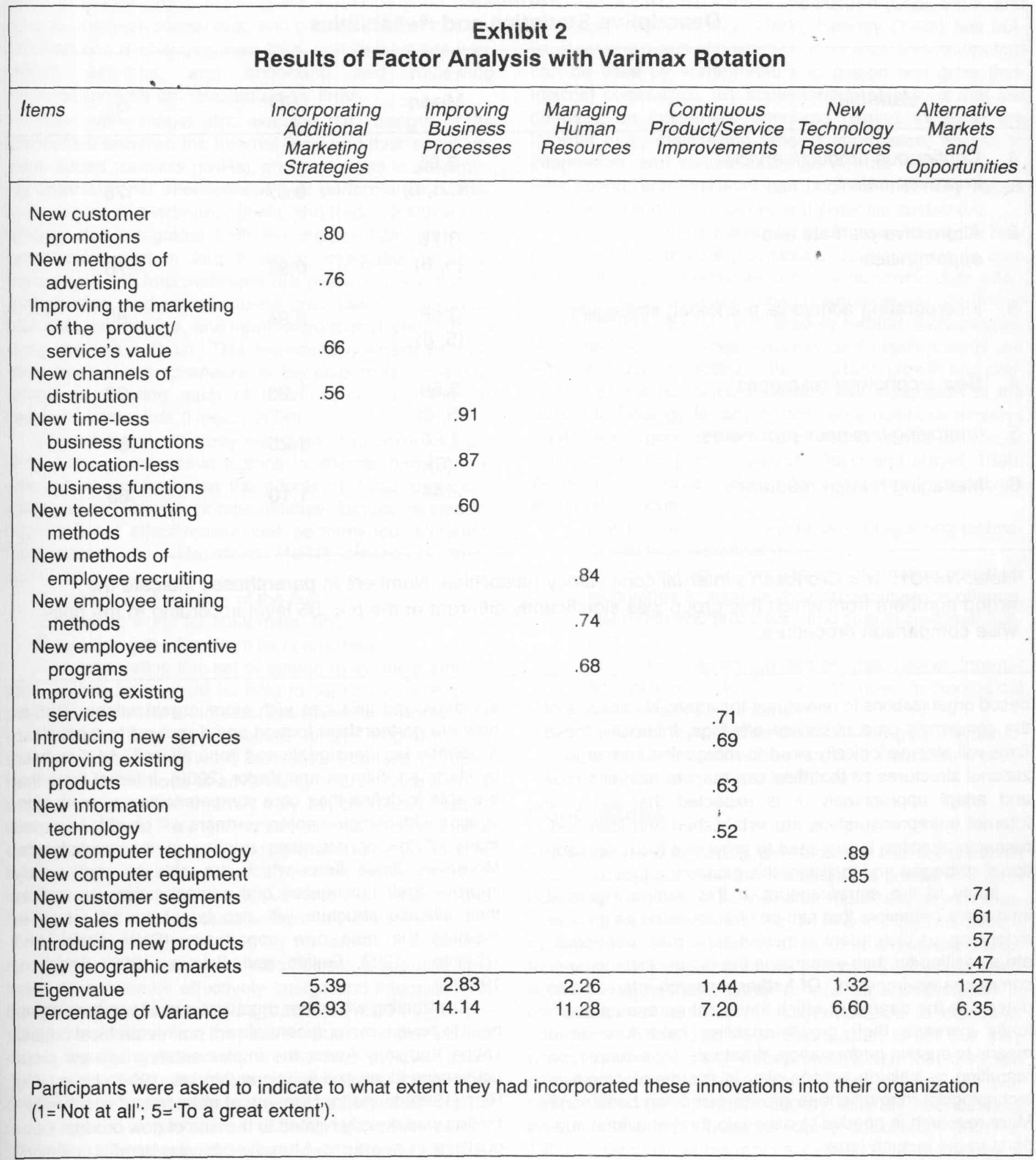




\section{Exhibit 3}

Descriptive Statistics and Reliabilities

Variable

Mean

$S D$

$\alpha$

1. Continuous product/service

improvements

3.85

$(4,5,6)$

0.87

.75

2. Alternative markets and

3.78

opportunities

0.82

3. Incorporating additional marketing strategies

4. New technology resources

5. Improving business processes

6. Managing human resources

Note: $\mathrm{N}=131 ; \alpha=$ Cronbach's internal consistency reliabilities. Numbers in parentheses indicate the group numbers from which this group was significantly different at the $p<.05$ level according to the pairwise comparison procedure.

based organizations to reevaluate the intangible benefits of the company's product/service offerings. Internally, these firms will also periodically need to reorganize their organizational structures so that they can react to market forces and adapt appropriately. It is expected that as more Internet entrepreneurships are established and identified, research attention is expected to grow and focus on additional strategies and tactics of this pioneering group.

Many of the entrepreneurs in this sample reported innovative behaviors that can be characterized as growthextending, as they adapt to market conditions and negotiate a position for their ventures in the rapidly expanding ecommerce environment. Of further research interest is to determine the degree to which these entrepreneurs eventually increase their growth-enabling behaviors as a means to sustain performance. What role, for example, do recruiting or training actions play in the development of technological innovations (a growth-extending behavior)? More research is needed to ascertain the behavioral supports found in such firms.

Additionally, more research should investigate how Internet entrepreneurs form and develop strategic rela- tionships and alliances with other organizations. That is, how are partnerships formed and dissolved to meet clearly defined business goals and imperatives? As discussed by Hartman, Sifonis, and Kador (2000), Internet firms that are able to define their core competencies and work sideby-side with complementary partners will be able to exploit many of the opportunities existing in the marketplace. Moreover, those firms which are able to continuously improve their businesses and competencies, as well as their alliance structure will also be at an advantage in meeting the next new opportunity (Choi, Stahl, and Whinston, 1997; Griffith and Palmer, 1999; Shannon, 1999).

Contracting with other organizations allows the netpreneur to have a more decentralized, nonhierarchical organization that may foster the implementation of new product/service ideas and solutions (Morino, 1999). Kelley and Rice (1999) found that the rate of alliance and interfirm formation was directly related to the rate of new product introductions in new firms. Moreover, having interfirm relationships that are fluid may also be necessary in the marketing and distribution of information about the value of the firm's 
products and services. Alternative methods of marketing found in the electronic marketplace that depend on business-to-business cooperation and communication include: soliciting and exchanging web links, soliciting listings from search services, and endorsing and reviewing products/services on newsgroups by firms.

More work should also examine the strength of the association between the Internet firms and their suppliers, value-added resellers (VARs), and customers in determining organizational effectiveness and performance. Valuechain migration (Hartman, Sifonis, and Kador, 2000) is one strategy that integrates both the supply-chain and customer-facing system into a single, integrated process. Innovations and improvements are made in the ordering. configuration, and manufacturing processes to bring realtime data, knowledge, and information to multiple partners along the value chain. This increased connectivity may allow Internet entrepreneurs to become responsive and flexible to meeting each of their customers' particular needs and demands (Neese, 2000).

While the present study was able to uncover multiple dimensions of innovative actions in Internet firms, future research should examine the effects of these ideas and solutions on several nonquantitative factors related to organizational effectiveness and performance. McGrath, Venkatraman, and MacMillan (1992) emphasize three such factors:

1. enhancing the value of the firm,

2. creating worth for customers, and

3 . insulating the firm from its competition.

By incorporating this set of criteria to evaluate innovations, researchers would be able to capture a more complete assessment of an Internet entrepreneur's innovations and solutions from an immediate and/or long-term perspective. For example, while the financial benefits of implementing new methods of advertising or promoting a product or service on the Internet may not be readily visible, such innovations may give the business a sustainable competitive advantage in building brand loyalty and customer satisfaction. Over a period of time, however, these innovations may lead to positive financial rewards and benefits for all involved stakeholders in the Internet firm.

As more entrepreneurs enter the arena of electronic commerce, future research is also needed to examine how these entrepreneurs effectively design and integrate new business processes and practices. Although the researchers believe that they have made an important first step in identifying dimensions of innovative behavior associated with and found inside Internet firms, more work should concentrate further on how these innovations relate to changes in organizational training and development, channel management, and client and customer relationships. These are all particularly relevant given that the expanded description of electronic commerce includes on- line information technology and communication that is used to enhance customer service and support (Choi, Stahl, and Whinston, 1997; Koshiur, 1997). Keeney (1999) has outlined several areas of customers' concerns and values that can be used by entrepreneurs to design and grow their Internet businesses. By implementing objectives that are centered on customers' concerns related to using the Internet (e.g., maximizing product information, access to information, and convenience, as well as minimize cost, time spent), entrepreneurs can begin to meet the values and demands of their current and potential customers.

In addition, future research should also investigate how Internet entrepreneurs incorporate-developments in core and emerging technologies such as electronic data interchange (EDI), databases, data communications, electronic fund transfers (EFTs), and security-related technologies. Many technological improvements and developments are seen as important factors to the long-term growth and profitability of the business. Selection and integration of the correct technology for any e-commerce business employs capital and organizational efficiency and serves as a foundation for building the business (Davis and Meyer, 1998; Weintraut and Davis, 1999). Additional research questions should also focus on:

- In what manner are key decisions regarding technological improvements made?

- How do entrepreneurs use the information from their technology to improve their product/service offering, marketing and promotion, and overall customer support?

- What are the driving forces that propel Internet entrepreneurs to implement new technological advances in their business?

- How do they evaluate their technological infrastructure and competencies in order to meet their e-commerce strategies and initiatives?

\section{Conclusions}

The explosive commercial growth of the Internet presents both new opportunities and challenges to entrepreneurs in how they formulate, develop, and implement new innovations into their businesses. As Drucker (1998) has asserted, innovation is the specific function of entrepreneurship. Moreover, distinctive innovative behaviors appear to characterize the emerging group of Internet entrepreneurs in comparison to ventures not fully dedicated to electronic commerce. "What sets netpreneurs apart is not that they are different from other entrepreneurs, but that they are operating in a universe of transforming change. As pioneers of the new networked society, they are both defining and learning new ways of doing business" (Morino, 1999:1). Because of the rapid acceleration of technology, it is becoming more critical that Internet entrepreneurs have the ability to respond quickly to changes by bringing revo- 
lutionary new ideas into their businesses and the electronic marketplace.

In this way, they are creating new patterns of entrepreneurial behavior and performance. The results uncovered in this research represent one of the first empirical investigations into the processes associated with e-business founders. This study attempts to increase our understand- ing of the phenomena surrounding the formation and growth of these businesses, and has focused on the distinctive innovative actions of a group of these entrepreneurs. Exploring the direction of such behavior should facilitate the development of new entrepreneurial models for predicting the successful identification and exploitation of e-commerce opportunities.

\section{References}

Bangs, D. H., and Pinson, L. (1999). The Real World Entrepreneur. Chicago, IL: Upstart Publishing Company.

Choi, S., Stahl, D., and Whinston, A. (1997). The Economics of Electronic Commerce. Indianapolis, IN: Macmillan Technical Publishing.

Cohen, A., and Jordan, J. M. (1999). Electronic commerce: The next generation. Electronic Commerce. Ernst \& Young Center for Business Innovation.

Davis, S., and Meyer, C. (1998). Blur: The speed of change in the connected economy. New York: Warner Books.

Drucker, P. F. (1998). The discipline of innovation. Harvard Business Review, 76 (6), 149-157.

Forrester Research (1999). E-commerce by the numbers. Cited at: http://www.net-profit-center.net/bynumber.htm.

Griffith, D. A., and Palmer, J. W. (1999). Leveraging the web for corporate success. Business Horizons, January/February, 3-10.

Gundry, L., and Welsch, H. (in press). The ambitious entrepreneur: High-growth strategies of women-owned enterprises. Journal of Business Venturing.

Hartman, A., Sifonis, J., and Kador, J. (2000). Net Ready: Strategies for Success in the Economy. New York: McGraw-Hill.

lansiti, M., and MacCormack, A. (1997). Developing product on Internet time. Harvard Business Review, 75 (5), p. $108-117$.

International Data Corporation (1999). E-commerce by the numbers. Cited' at: http://www.net-profitcenter.net/bynumber.htm.

Kecharananta, N., and Baker, H. G. (1999). Capturing entrepreneurial values. Journal of Applied Social Psychology, 29(4), 820-833.

Keeney, R. (1999). The value of Internet commerce to the customer. Management Science, April, 533-542.

Kelley, D., and Rice, M. (1999). Sustaining innovation in the new firm: The role of technology portfolios and alliance formation. In P. Reynolds et al. (eds.), Frontiers of Entrepreneurship Research. Wellesley, MA: Babson College.

Koshiur, D. (1997). Understanding Electronic Commerce. Redmond, WA: Microsoft Press.

Lange, J. E. (1999). Entrepreneurs and the Internet: The great equalizer. In J. Timmons (ed.), New Venture Creation (pp. 175-211). Boston: Irwin McGraw-Hill.

McGrath, R. G., Venkatraman, S., and MacMillan, 1. C. (1992). Measuring outcomes of corporate venturing: An alternative perspective. Academy of Management Best Paper Proceedings, August, Las Vegas, NV, 85-89. 
Miller, R., and Blais, R. A. (1992). Configurations of innovation: Predictable and maverick modes. Technology Analysis and Strategic Management, 4 (4), 363-386.

Morino, M. (1999). Netpreneurs: A new breed of entrepreneur. E-Commerce, May.

Neese, T. (2000). Report gives new trends on e-commerce evolution, communication changes. The Journal Record, January 24, http://www.journalrecord.com.

Nunnally, J. (1978). Psychometric Theory. New York: McGraw-Hill.

Oliva, R. A. (1998). Match your web page to your mission. Marketing Management, 7(4), 38-41.

Pistrui, D. (1999). Growth intentions and expansion plans of new entrepreneurs in transforming economies: An investigation into family dynamics, entrepreneurship and enterprise development. Technical Report. Universitat Autonoma de Barcelona.

Pistrui, D., Liao, J., and Welsch, H. (1998). Entrepreneurial expansion plans: An empirical investigation of infrastructure predictors. Paper presented at Research in Entrepreneurship (RENT XII). Lyon, France: November $26-27$

Shannon, J. (1999). Net brands lead by innovation. Marketing Week, 22, 28.

Weintraut, J. N., and Davis, J. (1999). Building the bulletproof net start-up: The five critical ingredients of online success. Business 2.0 (http://business2.com).

\section{NESE}

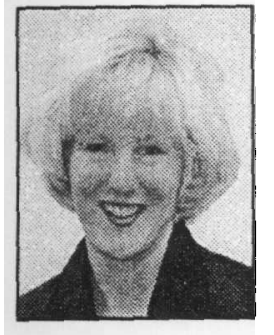

Jill Kickul is an assistant professor of management in the Charles H. Kellstadt Graduate School of Business at DePaul University where she teaches courses on entrepreneurship strategy and management strategy. Her research interests include entrepreneurial intentions and behaviors and strategic and innovation processes in startup ventures. Dr. Kickul's research has been published in the Journal of Small Business Management, Entrepreneurship and Regional Development, Journal of Business Ethics, and Journal of Business and Psychology. She has worked as a management consultant and conducted training in the areas of strategic analysis and planning and leadership development.

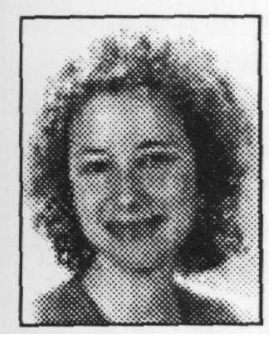

Lisa K. Gundry, an associate professor of management in the Charles H. Kellstadt Graduate School of Business at DePaul University, teaches courses on creativity in business and entrepreneurship and new venture management. Dr. Gundry is director of the Ryan Center for Creativity and Innovation at DePaul. She has coauthored two books and written articles for several journals, including Journal of Business Venturing, Journal of Small Business Management, Family Business Review, Journal of Developmental Entrepreneurship, and Organizational Dynamics. She conducts research and consults with organizations on issues of small business development and creativity and innovation. 